\title{
Longitudinal-size Trend in Eight Species of Centrobolus
}

\section{Cooper Mark}

Department of Animal, Plant and Environmental Sciences, University of the Witwatersrand, Johannesburg 2050, South Africa

Received: $1^{\text {st }}$ March, 2020

Accepted: $20^{\text {th }}$ March, 2020

Published online: 21 $1^{\text {st }}$ March, 2020

https://doi.org/10.33745/ijzi.2020.v06i01.005

\begin{abstract}
Bergmann's eco-geographical rule maintained within a taxonomic clade, populations and species of larger size were found in colder environments, and species of smaller size were found in warmer regions. It was tested in the millipede genus Centrobolus with reversed sexual size dimorphism (SSD). Two factors were measured from eight Centrobolus species -- body lengths $(\mathrm{mm})$ and widths $(\mathrm{mm})$. Centrobolus female widths were positively related to longitude $\left(\mathrm{r}=0.6474, \mathrm{r}^{2}=0.4191, \mathrm{n}=8, \mathrm{p}=0.082656\right)$. The squat species, $C$. digrammus occurred at the western tips of South Africa $\left(18.433^{\circ} \mathrm{E}\right)$ while thinner species, C. inscriptus and C. anulatus were found in east $\left(31.716^{\circ} \mathrm{E}\right)$. In between these two longitudes all the medium sized species ranged. This agrees with Bergmann's rule.
\end{abstract}

Keywords: Bergmann's, Clade, Cline, Dimorphism, Ecology, Size

Citation: Cooper Mark : Longitudinal-size trend in eight species of Centrobolus. Intern. J. Zool. Invest. 6 (1): 58-64, 2020. https://doi.org/10.33745/ijzi.2020.v06i01.005

\section{Introduction}

Bergmann's rule is an ecogeographical rule which states that within a broadly distributed taxonomic clade, populations and species of larger size are found in colder environments, and species of smaller size are found in warmer regions and was originally formulated in terms of species within a genus (Bergmann, 1847). Evidence for and against Bergmann's rule follows an even distribution in arthropods (Blanckenhorn and Demont, 2004).
Diplopoda are important environmental indicators and under-represented in analyses of invertebrate Sexual Size Dimorphism (SSD) which is the phenotypic condition where the two sexes of the same species exhibit different characteristics beyond the differences in their sexual organs (Maggenti et al., 2008). Common sexual differences are known to occur in body mass, length, width and leg dimensions of over half the taxa studied (Hopkin and Read, 1992; Barnett 
and Telford, 1993, 1994, 1996; Barnett et al., 1993, 1995; Van Aarde et al., 1996; Cooper M., 2016, 2017, 2018 a-h, 2019 a-j, 2020 a, b, c; Cooper MI., 1998, 2014 a, b, 2015 a, b, 2016 ar, 2017 a-g, 2018 a-e, 2019). Diplopods resemble invertebrates in SSD is reversed (Cooper M., 2018 c).

The forest clade Centrobolus of pachybolid millipedes belonging to the Order Spirobolida is distributed along the eastern coast of southern Africa (Cooper MI., 1998; Pitz and Sierwald 2010). They consist of brightly coloured (aposematic) species with concentrations around coastal bush or forests (Cooper MI., 1998). Their terrestrial habits make them ideal organisms for testing Bergmann's rule. In the present study SSD in the forest genus Centrobolus was investigated in eight species and 2 factors determining a response in SSD (length and width) recorded. Data wee checked for a correlation with longitude.

\section{Materials and Methods}

Two factors were obtained from eight Centrobolus species: (1) body length (mm) in placing individuals collected in South Africa alongside a plastic rule (calibrated in $\mathrm{mm}$ ); and (2) horizontal tergite width ( $\mathrm{mm}$ ) with Vernier calipers. The basic descriptive statistics; mean, standard deviation (SD) and $\mathrm{CV}$ of length and width were checked for Pearson's correlations with latitudinal, available at https://www.socscistatistics.com /tests/pearson/default.aspx. All estimates were standardized as length per degree longitude (Table 1). A correlation was performed, available at https://www.socsci statistics.com/pvalues/pearsondistribution.as px.

\section{Results}

Across Centrobolus male lengths not correlated to longitude but female widths (Fig. 1) were correlated $\left(r=0.6474, r^{2}=0.4191, n=8\right.$, $\mathrm{p}=0.082656$ ). The wider species, $C$. digrammus occurred at the western tip of South Africa found at Admirals Waterfall, Simon's Town (34.S; 18.433E). The thinner species, $C$. inscriptus and $C$. anulatus were found at Twin Streams farm, Mtunzini (-28.98S; 31.716E). Between these two extremes all the mediumsized species ranged.

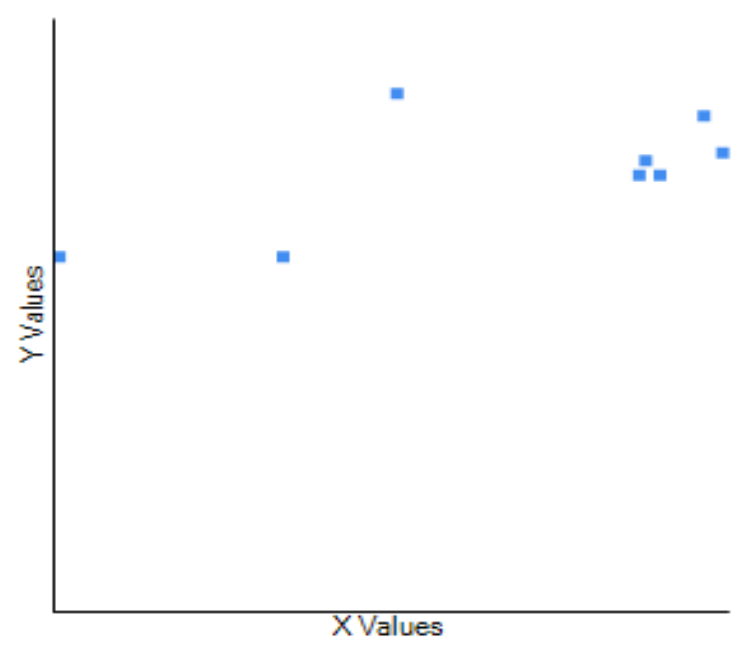

Fig. 1: Correlation of female width across longitude

\section{Discussion}

The data presented here for Centrobolus show a moderate positive correlation between female size and longitude. This result may not change the distribution of evidence from an even distribution in arthropods (Park, 1949; David and Bocquet, 1975; Londsday and Levinton, 1985; Cushman et al., 1993; Atkinson, 1994; Barlow, 1994; Van Voorhies, 1996; Mousseau, 1997; Partridge and Coyne, 1997; Karan et al., 1998; Arnett and Gotelli, 1999 a, b; van't Land et al., 1999; Loeschcke et al., 2000; Belk and Houston, 2002; Chown and 
Table 1: Male (m) and female (f) length and width's means ( $\mu$ ), standard deviation (SD) and coefficients of variation (CV) in Centrobolus spp. Original data based on descriptions of Cooper (2018), Lawrence (1967) and Schubart (1966)

\begin{tabular}{|c|c|c|c|c|c|c|}
\hline \multirow[t]{4}{*}{ Species } & Male & Female & Male & Female & $\begin{array}{l}\text { Lat., } \\
\text { Lon. }\end{array}$ & $\mathrm{N}$ \\
\hline & Length & Length & Width & Width & $\mathrm{S}, \mathrm{E}$ & $\mathrm{m}, \mathrm{f}$ \\
\hline & $\mu \pm \mathrm{SD}$ & $\mu \pm S D$ & $\mu \pm S D$ & $\mu \pm S D$ & & \\
\hline & $\mathrm{CV}$ & $\mathrm{CV}$ & $\mathrm{CV}$ & $\mathrm{CV}$ & & \\
\hline \multirow[t]{2}{*}{ anulafus } & $69 \pm 5.069517$ & $63 \pm 7.761599$ & $5.35333 \pm 0.46176$ & $5.86167 \pm 0.68115$ & -28.88 & 5,12 \\
\hline & 7.34712609 & 10.1724758 & 8.62565917 & 11.6204085 & 30.81 & \\
\hline \multirow[t]{2}{*}{ digrammus } & $49.9 \pm 2.1$ & $54.5 \pm 5.4$ & $4.0 \pm 0.1$ & $4.8 \pm 0.3$ & -34.19 & 6,6 \\
\hline & 4.20841683 & 9.90825688 & 2.5 & 6.25 & 18.433 & \\
\hline \multirow[t]{2}{*}{ fulgidus } & $56.2 \pm 2.5$ & $63.5 \pm 5.2$ & $5.4 \pm 0.2$ & $6.2 \pm 0.4$ & -29.39 & 11,1 \\
\hline & 4.44839858 & 8.18897638 & 3.7037037 & 6.4516129 & 32.100 & \\
\hline \multirow[t]{2}{*}{ inscriptus } & $67.4 \pm 2.9$ & $63.0 \pm 3.6$ & $5.9 \pm 0.2$ & $6.7 \pm 0.3$ & -28.98 & 88,88 \\
\hline & 4.30267062 & 5.71428571 & 3.38983051 & 4.47761194 & 31.716 & \\
\hline \multirow[t]{2}{*}{ Inurencit } & $43.125 \pm 2.64237$ & $43 \pm 0$ & $4.6875 \pm 0.2031$ & $5.9 \pm 0$ & -29.618 & 8,1 \\
\hline & 6.12723478 & 2.3255814 & 4.3328 & 16.9491525 & 30.383 & \\
\hline \multirow[t]{2}{*}{ raber } & $57.8 \pm 2.6$ & $62.3 \pm 6.3$ & $5.0 \pm 0.2$ & $6.1 \pm 0.4$ & -30.667 & 18,18 \\
\hline & 4.4982699 & 10.1123596 & 4 & 6.55737705 & 30.513 & \\
\hline \multirow[t]{2}{*}{ sagutinus } & $48.5 \pm 1.73205$ & $47 \pm 4.63681$ & $6.225 \pm 0.17078$ & $6.98 \pm 0.249$ & 33.767 & 4,5 \\
\hline & 3.57123711 & 9.86555319 & 2.74345382 & 3.56733524 & 25.396 & \\
\hline \multirow[t]{2}{*}{ silonanus } & $45.2 \pm 2.04939$ & $43.8 \pm 6.76018$ & $4.42 \pm 0.13038$ & $4.8 \pm 0.6442$ & -34.049 & 5,5 \\
\hline & 4.53404867 & 15.4342009 & 2.94977376 & 13.4208333 & 23.047 & \\
\hline
\end{tabular}

Klok, 2003; Johansson, 2003; Blanckenhorn and Demont, 2004; Nesrine and Enghoff, 2011; Hassall et al., 2013; Vinarski, 2013; Pallarés et al., 2018; Gérard et al., 2018). It may suggest "Direct evidence for the adaptive nature of Bergmann clines which requires that the fitness optimum lies at smaller body sizes at warm temperatures (or in warm habitats), typically involving demonstration of temperature dependent trade-offs. Such demonstrations are rare. The best, but by no means conclusive evidence to date in this regard has been presented by McCabe and Partridge (1997) and Reeve et al. (2000). The evidence in support for this was found in showing longer-lighter male millipedes occurred at higher temperatures and lower latitudes, providing support for directional selection on male size in 126 arthropod species from 16 taxonomic orders (Cooper M., 2019 a; Horne et al., 2019). The evidence for the rule is supported on a global scale and suggests fecundity selection on female width (Cooper M., 2016). Because males and females differ in volumes and it can be reduced to sexual selection for male length and fecundity selection for female width (Darwin, 1874; Cooper M., 2019 a).

The present study is in agreement with the prediction for northern hemisphere European millipedes and provides supporting evidence from the southern hemisphere. The general 
trend for terrestrial invertebrates to be larger in the tropics also holds for millipedes. Among Juliformia, the huge species of Spirostreptidae, Harpagophoridae, Rhinocricidae, and Pachybolidae, all occur at low latitudes. In Europe, the largest julids (Pachyiulus spp., up to $10 \mathrm{~cm}$ long) only occur in the south. Central and northern European species seldom exceed $3 \mathrm{~cm}$. The northernmost European juliformian is the minute blaniulid Protemiulus fuscus" (Enghoff, 1992). The trend is in agreement with the Moreau-Lack rule which hypothesized that fecundity increases with increasing latitude/longitude (Moreau, 1944; Lack, 1954). The longitudinal trend with size in Centrobolus suggests it is matched with increasing terrestrial temperature (Horne et al., 2015). This is an aspect of Arthropods life history (Chapin, 2017). And for this reason the longitudinal trends may correlate with the abundance and length of the breeding season (Supriya et al., 2019).

\section{Conclusion}

The data presented here show a significant correlation and regression of Centrobolus female width across longitude. This agrees with Bergmann's rule.

\section{References}

Arnett AE and Gotelli NJ. (1999 a) Geographic variation in life-history traits of the ant lion, Myrmeleon immaculatus: Evolutionary implications of Bergmann's rule. Evol. 53: 1180-1188.

Arnett AE and Gotelli NJ. (1999 b) Bergmann's rule in the ant lion Myrmeleon immaculatus: Geographic variation in body size and heterozygosity. J. Biogeogr. 26: 275-283.

Atkinson D. (1994) Temperature and organism size-a biological law for ectotherms? Adv. Ecol. Res. 25: 158.

Barlow ND. (1994) Size distributions of butterfly species and the effect of latitude on species sizes. Oikos 71: 326-332.
Barnett M and Telford SR. (1993) The functional morphology of gonopods as evidence for sperm competition in savannah millipedes. In: Abstracts, 9th International Congress of Myriapodology, Paris, France, 26-31.07.1993, 11.

Barnett M and Telford SR. (1994) The timing of insemination and its implications for sperm competition in a millipede with prolonged copulation. Anim. Behav. 48: 482-484.

Barnett M and Telford SR. (1996) Sperm competition and the evolution of millipede genitalia. In: Geoffroy JJ., Mauriès JP. and Nguyen Duy-Jacquemin M. (eds.): Acta Myriapodologica. Mém. Mus. Natl, Hist. Nat. 169: 331-339.

Barnett M, Telford SR and Tibbles BJ. (1995) Female mediation of sperm competition in the millipede Alloporus uncinatus (Diplopoda: Spirostreptidae). Behav. Ecol. Sociobiol. 36: 413-419.

Barnett M, Telford SR and de Villiers CJ. (1993) Sperm displacement in a millipede? An investigation into the genital morphology of the southern African spirostreptid millipede Orthoporus pyrhocephalus. J. Zool. 231: 511-522.

Belk MC and Houston DD. (2002) Bergmann's rule in ectotherms: A test using freshwater fishes. Am. Nat. 160: 803-808.

Bergmann C. (1847) Über die Verhältnisse der Wärmeökonomie der Thiere zu ihrer. Gottinger Studien. 3: 595-708.

Blanckenhorn WU and Demont M. (2004) Bergmann and converse Bergmann Latitudinal Clines in arthropods: Two ends of a continuum? Integr. Comp. Biol. 44: 413-424.

Chapin KJ. (2017) Arthropod Life History. In: Vonk J, and Shackelford T. (eds.): Encyclopedia of Animal Cognition and Behavior. Springer, Cham.

Chown SL and Klok CJ. (2003) Altitudinal body size clines: Latitudinal effects associated with changing seasonality. Ecography. 26: 445-455.

Cushman JH, Lawton JH and Manly BFJ. (1993) Latitudinal patterns in European ant assemblages: Variation in species richness and body size. Oecologia. 95: 30-37.

Cooper M. (2016) Post-insemination associations between males and females in Diplopoda. J. Entomol. Zool. Stud. 4: 283-285.

Cooper M. (2017) Re-assessment of rensch's rule in Centrobolus. J. Entomol. Zool. Stud. 5: 2408-2410.

Cooper M. (2018 a) Allometry in Centrobolus. J. Entomol. Zool. Stud. 6: 284-286. 
Cooper M. (2018 b) A review of studies on the fire millipede genus Centrobolus (Diplopoda: Trigoniulidae). J. Entomol. Zool. Stud. 6: 126-129.

Cooper M. (2018 c) Centrobolus anulatus reversed sexual size dimorphism. J. Entomol. Zool. Stud. 6: 1569-1572.

Cooper M. (2018 d) Centrobolus dubius (Schubart, 1966) monomorphism. Int. J. Res. Stud. Zool. 4: 1721.

Cooper M. (2018 e) Centrobolus lawrencei (Schubart, 1966) monomorphism. Arthropod. 7: 82-86.

Cooper M. (2018 f) Centrobolus sagatinus sexual size dimorphism based on differences in horizontal tergite width. J. Entomol. Zool. Stud. 6: 275-277.

Cooper M. (2018 g) Centrobolus silvanus dimorphism based on tergite width. Glob. J. Zool. 3: 003-005.

Cooper M. (2018 h) Centrobolus size dimorphism breaks Rensch's rule. Arthropod. 7: 48-52.

Cooper M. (2019 a) A review on studies of behavioural ecology of Centrobolus (Diplopoda, Spirobolida, Pachybolidae) in southern Africa. Arthropod. 8: 3844.

Cooper M. (2019 b) Xylophagous millipede surface area to volume ratios are size-dependent in forests. Arthropod. 8: 127-136.

Cooper M. (2019 c) Size dimorphism in six juliform millipedes. Arthropod. 8: 137-142.

Cooper M. (2019 d) Centrobolus titanophilus size dimorphism shows width-based variability. Arthropod. 8: 80-86.

Cooper M. (2019 e) Non-significant intersexual differences in millipede mass. J. Entomol. Zool. Stud. 7: 763-765.

Cooper M. (2019 f) Quasi-experimental determination of a mass standard in the forest millipede Centrobolus inscriptus. J. Entomol. Zool. Stud. 7: 772774.

Cooper M. (2019 g) Underlying sperm precedence pattern in the millipede Centrobolus inscriptus (Attems, 1928) (Diplopoda: Pachybolidae). J. Entomol. Zool. Stud. 7: 1066-1069.

Cooper M. (2019 h) When is the change in sperm precedence in the millipede Centrobolus inscriptus (Attems, 1928) (Diplopoda, Pachybolidae)? J. Entomol. Zool. Stud. 7: 183-186.

Cooper M. (2019 i) Julid millipede and spirobolid millipede gonopod functional equivalents. J. Entomol. Zool. Stud. 7: 333-335.
Cooper M. (2019 j) Size dimorphism and directional selection in forest millipedes. Arthropod. 8: 102109.

Cooper M. (2020 a) Year-round correlation between mass and copulation duration in forest millipedes. Arthropod. 9: 15-20.

Cooper M. (2020 b) Kurtosis and skew show longer males in Centrobolus. Arthropod. 9: 21-26.

Cooper M. $(2020$ c) Zoomorphic variation with copulation duration in Centrobolus. Arthropod. 9: DOI: $10.13140 /$ RG.2.2.24762.13768

Cooper MI. (1998) Mating dynamics of South African forest millipedes Centrobolus Cook (Diplopoda: Pachybolidae). Thesis for Master of Science, Cape Town, University of Cape Town, South Africa.

Cooper MI. (2014 a) Sex ratios, mating frequencies and relative abundance of sympatric millipedes in the genus Centrobolus Cook. Arthropod. 3: 174-176.

Cooper MI. (2014 b) Sexual size dimorphism and corroboration of Rensch's rule in Chersastus millipedes (Diplopoda: Trigoniulidae). J. Entomol. Zool. Stud. 2: 264-266.

Cooper MI. (2015 a) Competition affected by re-mating interval in a myriapod. J. Entomol. Zool. Stud. 3: 7778.

Cooper MI. (2015 b) Elaborate gonopods in the myriapod genus Chersastus. J. Entomol. Zool. Stud. 3: 235-238.

Cooper MI. (2016 a) Confirmation of four species of Centrobolus Cook based on gonopod ultrastructure. Int. J. Entomol. Res. 1: 7-9.

Cooper MI. (2016 b) Confirmation of four species of Centrobolus Cook based on gonopod ultrastructure. J. Entomol. Zool. Stud. 4: 389-391.

Cooper MI. (2016 c) Do females control the duration of copulation in the aposematic millipede Centrobolus inscriptus? J. Entomol. Zool. Stud. 4: 623-625.

Cooper MI. (2016 d) Fire millipedes obey the female sooner norm in cross mating Centrobolus Cook. J. Entomol. Zool. Stud. 4: 173-174.

Cooper MI. (2016 e) Gonopod mechanics in Centrobolus Cook. J. Entomol. Zool. Stud. 4: 152-154.

Cooper MI. (2016 f) Heavier-shorter-wider females in the millipede Centrobolus inscriptus (Attems). J. Entomol. Zool. Stud. 4: 509-510.

Cooper MI. (2016 g) Instantaneous insemination in the millipede Centrobolus inscriptus (Attems) determined by artificially terminated mating. J. Entomol. Zool. Stud. 4: 487-490. 
Cooper MI. (2016 h) Sexual bimaturism in the millipede Centrobolus inscriptus (Attems). J. Entomol. Zool. Stud. 4: 86-87.

Cooper MI. (2016 i) Sexual conflict over the duration of copulation in Centrobolus inscriptus (Attems). J. Entomol. Zool. Stud. 4: 852-854.

Cooper MI. (2016 j) Sperm dumping in Centrobolus inscriptus (Attems). J. Entomol. Zool. Stud. 4: 394395.

Cooper MI. (2016 k) Sperm storage in Centrobolus Cook and observational evidence for egg simulation. J. Entomol. Zool. Stud. 4: 127-129.

Cooper MI. (2016 l) Sperm storage in Centrobolus inscriptus (Attems). J. Entomol. Zool. Stud. 4: 392393.

Cooper MI. (2016 m) Symmetry in ejaculate volumes of Centrobolus inscriptus (Attems). Int. J. Entomol. Res. 1: 14-15.

Cooper MI. (2016 n) Symmetry in ejaculate volumes of Centrobolus inscriptus (Attems). J. Entomol. Zool. Stud. 4: 386-387.

Cooper MI. (2016 o) Syncopulatory mate-guarding affected by predation in the aposematic millipede Centrobolus inscriptus in a swamp forest. J. Entomol. Zool. Stud. 4: 483-484.

Cooper MI. (2016 p) Tarsal pads of Centrobolus Cook. J. Entomol. Zool. Stud. 4: 385-386.

Cooper MI. (2016 q) The influence of male body mass on copulation duration in Centrobolus inscriptus (Attems). J. Entomol. Zool. Stud. 4: 804-805.

Cooper MI. (2016 r) The relative sexual size dimorphism of Centrobolus inscriptus compared to 18 congenerics. J. Entomol. Zool. Stud. 4: 504-505.

Cooper MI. (2017 a) The effect of female body width on copulation duration in Centrobolus inscriptus (Attems). J. Entomol. Zool. Stud. 5: 732-733.

Cooper MI. (2017 b) Size matters in myriapod copulation. J. Entomol. Zool. Stud. 5: 207-208.

Cooper MI. (2017 c) Relative sexual size dimorphism in Centrobolus digrammus (Pocock) compared to 18 congenerics. J. Entomol. Zool. Stud. 5: 1558-1560.

Cooper MI. (2017 d) Relative sexual size dimorphism in Centrobolus fulgidus (Lawrence) compared to 18 congenerics. J. Entomol. Zool. Stud. 5: 77-79.

Cooper MI. (2017 e) Relative sexual size dimorphism Centrobolus ruber (Attems) compared to 18 congenerics. J. Entomol. Zool. Stud. 5: 180-182.

Cooper MI. (2017 f) Allometry of copulation in worm like millipedes. J. Entomol. Zool. Stud. 5: 1720-1722.
Cooper MI. (2017 g) Copulation and sexual size dimorphism in worm-like millipedes. J. Entomol. Zool. Stud. 5: 1264-1266.

Cooper MI. (2018 a) Allometry for sexual dimorphism in millipedes (Diplopoda). J. Entomol. Zool. Stud. 6: 91-96.

Cooper MI. (2018 b) Sexual dimorphism in pill millipedes (Diplopoda). J. Entomol. Zool. Stud. 6: 613-616

Cooper MI. (2018 c) Sexual size dimorphism and the rejection of Rensch's rule in Diplopoda (Arthropoda). J. Entomol. Zool. Stud. 6: 1582-1587.

Cooper MI. (2018 d) Trigoniulid size dimorphism breaks Rensch. J. Entomol. Zool. Stud. 6: 1232-1234.

Cooper MI. (2018 e) Volumes of Centrobolus albitarsus (Lawrence, 1967). Int. J. Entomol. Res. 3: 20-21.

Cooper MI. (2019) Lawrence's red millipede Centrobolus lawrencei shows length-based variability and size dimorphism. J. Entomol. Zool. Stud. 7: 1037-1039.

Darwin CR. (1874) Descent of man, and selection in relation to sex. (Second ed.). London, Murray.

David JR and Bocquet C. (1975) Similarities and differences in latitudinal adaptation of two Drosophila sibling species. Nature 257: 588-590.

Enghoff H. (1992) The size of a Millipede. Berichte der naturhistorisch-medizinischen Vereins Innsbruck, Suppl. 10.

Gérard $M$, Van Der Planck M, Franzén $M$, Kuhlmann $M$, Potts SG, Rasmont P, Schweiger 0 and Michez D. (2018) Patterns of size variation in bees at a continental scale: does Bergmann's rule apply? Oikos 127: 1095-1103.

Hassall C, Keat S, Thompson DJ and Watts PC. (2013) Bergmann's rule is maintained during a rapid range expansion in a damselfly? Glob. Chang. Biol. 20: 475482.

Hopkin SP and Read HJ. (1992) The Biology of Millipedes. Oxford University Press, Oxford, UK.

Horne CR, Hirst A and Atkinson D. (2015) Temperature-size responses match latitudinal-size clines in arthropods, revealing critical differences between aquatic and terrestrial species. Ecol. Lett. 18: 327-335.

Horne CR, Hirst A and Atkinson D. (2019) A synthesis of major environmental body size clines of the sexes within arthropod species. Oecologia 190: 343-353.

Johansson F. (2003) Latitudinal shifts in body size of Enallagma cyathigerum (Odonata). J. Biogeogr. 30: 29-34. 
Karan D, Munjal AK, Gibert P, Moreteau B, Parkash R and David JR. (1998) Latitudinal clines for morphometrical traits in Drosophila kikkawai: A study of natural populations from the Indian subcontinent. Genet. Res. 71: 31-38.

Lack D. (1954) The natural regulation of animal numbers. Clarendon Press, Oxford.

Lawrence RF. (1967) The Spiroboloidea (Diplopoda) of the eastern half of Southern Africa. Ann. Nat. Mus. 18: 607-646.

Loeschcke V, Bundgaard J and Barker JSF. (2000) Variation in body size and life history traits in Drosophila aldrichi and D. buzzatii from a latitudinal cline in eastern Australia. Hered. 85: 423-433.

Lonsday DJ and Levinton JS. (1985) Latitudinal differentiation in copepod growth: An adaptation to temperature. Ecol. 66: 1397-1407.

Maggenti MA, Maggenti AR and Gardner S. (2008) Dictionary of Invertebrate Zoology. Zea EBooks, 1379.

McCabe J and Partridge L. (1997) An interaction between environmental temperature and genetic variation for body size for the fitness of adult female Drosophila melanogaster. Evolution 51: 1164-1174.

Moreau RE. (1944) Clutch-size: a comparative study, with special reference to African birds. Ibis 86: 286347.

Mousseau TA. (1997) Ectotherms follow the converse Bergmann's rule. Evolution 51: 630-632.

Nesrine A and Enghoff H. (2011) Copulatory-copulatory male succession and male slenderness in Ommatiulus sempervirilis n. sp., a new insular millipede from Tunisia (Diplopoda: Julida: Julidae). J. Zool. Syst. Evol. Res. 49: 285-291.

Pallarés S, Lai M, Abellán P, Ribera I and Sánchez-Fernández D. (2018) An interspecific test of Bergmann's rule reveals inconsistent body size patterns across several lineages of water beetles (Coleoptera: Dytiscidae): Bergmann's rule in water beetles. Ecol. Entomol. 44: 249-252.
Park O. (1949) Application of the converse Bergmann principle to the carabid beetle, Dicaelus purpuratus. Physiol. Zool. 22: 359-372.

Partridge L and Coyne J. (1997) Bergmann's Rule in ectotherms: is it adaptive? Evolution 51: 632-635.

Pitz KM and Sierwald P. (2010) Phylogeny of the millipede Order Spirobolida (Arthropoda: Diplopoda: Helminthomorpha). Cladistics. 26: 497525.

Reeve MW, Fowler K and Partridge L. (2000) Increased body size confers greater fitness at lower experimental temperature in male Drosophila melanogaster. J. Evol. Biol. 13:836-844.

Schubart O. (1966) Diplopoda III: Pselaphognatha, Opisthospermophora, Colobognatha. In: Hanstrom B, Brinck P, Rudebeck G (eds.). South Africa Animal Life 12: 86-89 and 118-120.

Supriya K, Moreau CS, Sam K and Price T. (2019) Analysis of tropical and temperate elevational gradients in arthropod abundance. Front. Biogeogr. 11: 1-11.

Van Aarde RJ, Ferreira SM and Kritzinger JJ. (1996) Millipede communities in rehabilitating coastal dune forests in northern KwaZulu/Natal, South Africa. J. Zool. 238: 703-712.

van't $L$ and J, van Putten P, Zwaan B, Kamping A and van Delden W. (1999) Latitudinal variation in wild populations of Drosophila melanogaster: Heritabilities and reaction norms. J. Evol. Biol. 12: 222-232.

Van Voorhies WA. (1996) Bergmann size clines: A simple explanation for their occurrence in ectotherms. Evolution 50: 1259-1264.

Vinarski M. (2013) On the application of Bergmann's rule to ectothermic organisms: The state of the art? Zh. Obshch. Biol. 74: 327-339. 